Thorax (1970), 25, 105.

\title{
Effect of hypothermia on lung compliance
}

\author{
CEDRICW. DEAL, JOHN C. WARDEN, IAN MONK \\ Unit of Clinical Investigation and Wellcome Laboratory, Royal North Shore Hospital, \\ Crows Nest, Sydney, Australia, 2065
}

\begin{abstract}
The changes in pulmonary compliance have been studied under conditions of total body hypothermia. Five groups of sheep were used; two groups were controls-one for the effects of anaesthesia and the other for normothermic biventricular bypass. The third group was cooled using a femoro-femoral arterio-venous shunt to $20^{\circ}-23^{\circ} \mathrm{C}$. The fourth group was cooled to $15^{\circ} \mathrm{C}$. and rewarmed using the Drew technique. The excised lungs of the remaining sheep were studied at $37^{\circ}$ and $15^{\circ} \mathrm{C}$. (fifth group). The controls showed little change in compliance. The cooled animals showed a decrease in compliance. In the group subjected to hypothermia by the Drew technique, the rewarming phase initially brought a return towards normal compliance. As the temperature rose to $24^{\circ}-30^{\circ} \mathrm{C}$. the improvement in compliance ceased and thereafter compliance decreased for two hours after rewarming. Histologically the lungs were normal. There was no compliance change caused by cooling the excised lungs.
\end{abstract}

Total body hypothermia is used often as an adjunct to medical and surgical treatment (Allen, Estes, and Mansberger, 1960 ; Gowen and Lindenmuth, 1961 ; Lorhan and Brookler, 1961 ; Michenfelder, Terry, Daw, MacCarty, and Uihlein, 1963 ; Harley, 1964). It is usually accepted as innocuous when used in this way or when used as an alternative to cardiopulmonary bypass (Bigelow, Callaghan, and Hopps, 1950 ; Drew, Keen, and Benazon, 1959). Even so, many changes occur in the course of hypothermia that are ill understood.

Hypothermia is used as a method for decreasing oxygen requirements, and frequently the period following hypothermia is one in which a high level of oxygenation is necessary, be it in the intraoperative phase or in the post-operative phase. Consequently, an unimpaired pulmonary function is of extreme importance.

We have not found any record of previous studies of pulmonary function during and after hypothermia. In this paper we have correlated changes in pulmonary compliance with varying levels of hypothermia in sheep.

\section{METHODS}

Nineteen healthy adult sheep were studied (weight range $30-35 \mathrm{~kg}$.). Anaesthesia was induced with an intravenous injection of thiopentone $(10-12 \mathrm{mg} . / \mathrm{kg}$.), the trachea was intubated with an 8.5 to $11 \mathrm{~mm}$. cuffed endotracheal tube, and the cuff was firmly inflated. The animal was given gallamine triethiodide $4 \mathrm{mg}$./ kg. intravenously, and ventilated using a semi-closed circle system with carbon dioxide absorption and a fresh gas flow of 3 litres of oxygen, 5 litres of nitrous oxide, and $0.5 \%$ halothane per minute. Mechanical ventilation was maintained throughout the study using a Bird Mark VII respirator which ventilated the anaesthesia rebreathing bag enclosed in a large glass bottle. Tidal volumes were in the vicinity of $1,100 \mathrm{ml}$. to ensure full expansion and standardization of measurements. Manual hyperinflation was performed for 15 seconds every 10 minutes and prior to each measurement of compliance (Mead and Collier, 1959 ; Judd and King, 1967), and this prevented obvious collapse from occurring.

In 16 sheep the chest was opened by a wide left antero-lateral thoracotomy, the left pleura was incised, and the right pleural cavity was opened in the midline anteriorly. All animals were anticoagulated with a dose of $3 \mathrm{mg} . / \mathrm{kg}$. of heparin intravenously. Polythene cannulae were placed in the left femoral artery and the pulmonary artery, and mean arterial pressures were measured with a mercury manometer. The oesophageal temperature was monitored with an Ellab electric thermometer, the probe tip lying at the level of the junction of the descending aorta and the aortic arch. Compliance was measured by inflating the lungs with $1,000 \mathrm{ml}$. of air using a calibrated perspex 'syringe' (Bendixen, Egbert, Hedley-Whyte, Laver and Pontoppidan, 1965 ; Sullivan, Patterson, Malm, Bowman, and Papper, 1966 ; Deal, Osborn, Ellis, and Gerbode, 1968). The rise in intrapulmonary pressure was read from a manometer mounted on the syringe, the rise being the steady level of pressure recorded at about 2 seconds after inflation (Dean and Visscher, 
1941 ; Guastavino, Wikinski, Andres, Donadei, and Quinterno, 1960).

In the remaining three sheep, the lungs and heart were removed in toto through a wide median sternotomy. The three pairs of lungs thus obtained were used as controls to observe the effect of hypothermia without perfusion. The excised lungs were placed in water-baths at $37^{\circ} \mathrm{C}$. and $15^{\circ} \mathrm{C}$. and the compliances were measured at the end of 30 minutes at each temperature.

The 16 intact sheep were divided into four groups. In group 1, three sheep were studied over a period of three hours of anaesthesia alone. In group 2 (three sheep), metal cannulae, $4 \mathrm{~mm}$. in diameter, were placed in a femoral artery and a femoral vein and were connected by $1 \cdot 0-\mathrm{cm}$. polythene tubing to a heat exchanger, thus forming an arterio-venous shunt (Fig. 1). These animals were cooled, to $20^{\circ} \mathrm{C}$. in two and to $23^{\circ} \mathrm{C}$. in the third, over a period of 60 minutes in two and 90 minutes in the third. Attempts at rewarming were unsuccessful as heart failure and ventricular fibrillation soon occurred.

In groups 3 and 4 , sheep had polythene cannulae $7 \mathrm{~mm}$. in diameter inserted into the right atrium and the left atrium, $5 \mathrm{~mm}$. in diameter into the pulmonary artery, and a metal cannula, $4 \mathrm{~mm}$. in diameter, into the right femoral artery, and connected by $1 \cdot 0-\mathrm{cm}$. polythene tubing, as in the technique of hypothermia described by Drew et al. (1959). Bypass of the right heart and the left heart was begun by circulating blood from the right atrium to the pulmonary artery and from the left atrium to the femoral artery using two occlusive roller pumps. A heat exchanger was incorporated into the left heart bypass line.

In group 3 (five sheep), body temperature was maintained at a steady $35^{\circ} \mathrm{C}$. whilst total heart bypass was

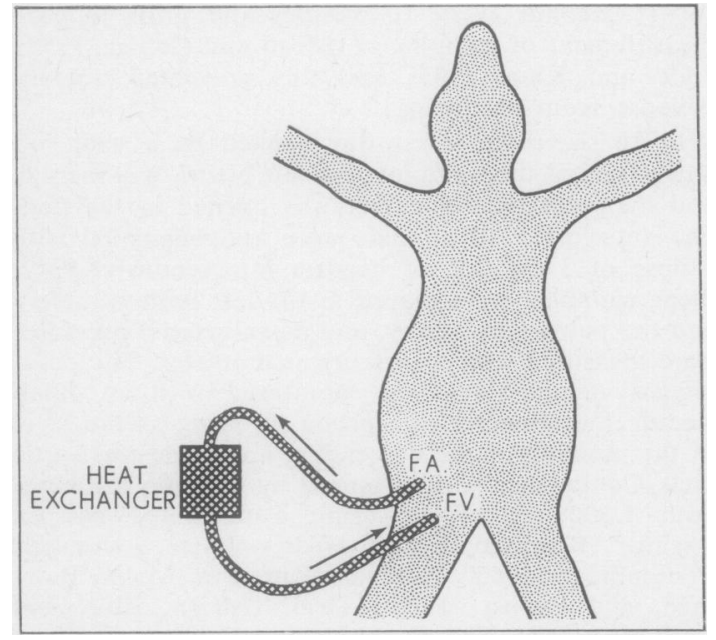

FIG. 1. Diagram of a sheep with a femoral artery (F.A.) to femoral vein $(F . V$.) bypass incorporating a heat exchanger in the line to produce hypothermia. maintained for 80 minutes. After 50 minutes ven $\frac{\overline{\bar{S}}}{\frac{5}{0}}$ tricular fibrillation was induced electrically and after? a further 20 minutes the heart was successfully $\frac{\overline{\bar{O}}}{\overline{\mathrm{D}}}$ defibrillated using an AC defibrillator.

In group 4 (five sheep), the body temperature was decreased to $15^{\circ} \mathrm{C}$. and then returned to $37^{\circ} \mathrm{C}$. Theo bypass started as partial on both sides only, becom-s ing total as the cardiac output fell with the decreasing $\vec{O}$ temperature. Ventricular fibrillation occurred as the temperature fell and sinus rhythm occurred spon-w taneously as the animals were rewarmed. The pumps? maintained a mean arterial blood pressure over $45 \times$ $\mathrm{mm}$. $\mathrm{Hg}$ at all times. As the vascular resistance felli Ringer's solution was added to the perfusate to main -1 tain the circulating volume and pressure. The pump. flows necessary to maintain the blood pressure variede between 3 and 4.5 litres/minute.

Samples of lung for histological examination were? taken at the end of studies by inflating lobes of lungs with a formalin solution prior to fixation and sections for microscopic examination.

\section{RESULTS}

In the sheep subjected to anaesthesia alone (group 1) little change in lung compliance occurredo over a three-hour period, and the initial and fina compliances are shown in Table $\mathbf{I}$.

T A B L E I

EFFECT OF ANAESTHESIA ALONE

\begin{tabular}{|c|c|c|}
\hline Sheep No. & $\begin{array}{c}\text { Initial } \\
\text { Compliance }\end{array}$ & $\begin{array}{c}\text { Final } \\
\text { Compliance }\end{array}$ \\
\hline $\begin{array}{l}1 \\
2 \\
3\end{array}$ & $\begin{array}{l}0 \cdot 110 \\
0 \cdot 100 \\
0.087\end{array}$ & $\begin{array}{l}0 \cdot 105 \\
0 \cdot 091 \\
0 \cdot 100\end{array}$ \\
\hline
\end{tabular}

Compliance is expressed in litres/cm. $\mathrm{H}_{2} \mathrm{O}$.

In group 2, the sheep were cooled using femoro femoral bypass. We have plotted the pressure taken to inflate the lungs with 1 litre of air agains time and have recorded the body temperature. I음 can be seen that the elasticity of the lungs steadily decreases with temperature fall (Fig. 2). The initia and final compliances are shown in Table II. Inf this group, the blood pressure fell steadily through out the study until ventricular fibrillation occurreck at a mean arterial pressure of about $30 \mathrm{~mm}$. Hget The pulmonary artery pressure never exceedec $11 \mathrm{~mm}$. $\mathrm{Hg}$ and was usually between 8 and $\mathrm{mm}$. $\mathrm{Hg}$, showing little change throughout th procedure.

In group 3, the sheep were subjested to biven $=0$ tricular bypass without cooling, and a period o? fibrillation was induced to simulate the event? occurring in the cooled group. Figure 3 shows the pressure needed for inflation of the lungs witto 


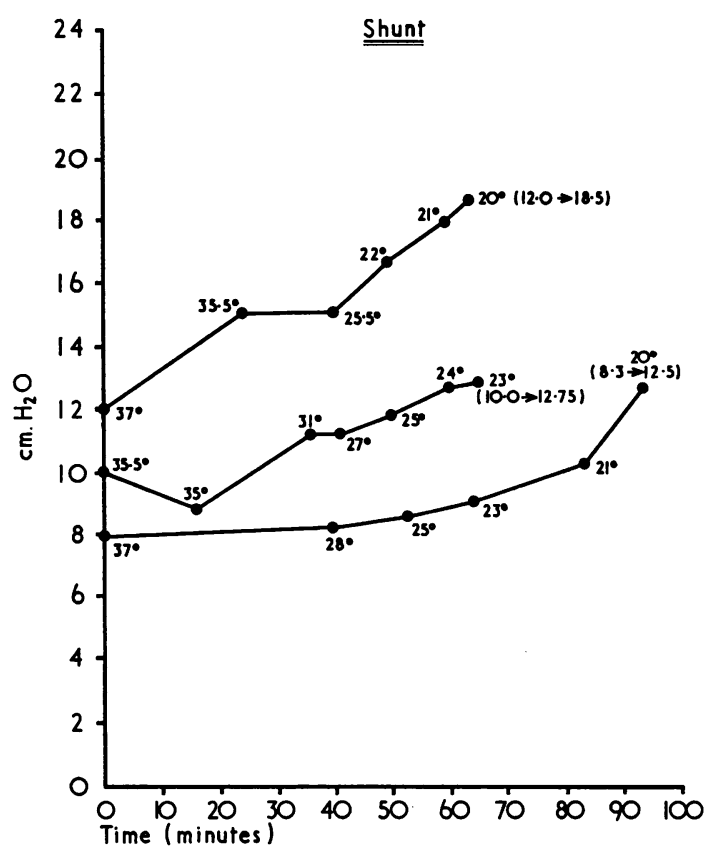

FIG. 2. Pressure-volume relationships of the lungs of three sheep subjected to hypothermia using a femoro-femoral shunt. As the temperature falls, increasingly higher pressures are required to inflate the lungs with 1 litre of air.

T A B L E I I

EFFECT OF COOLING WITH FEMORO-FEMORAL BYPASS

\begin{tabular}{c|cc|cc}
\hline No. & $\begin{array}{c}\text { Initial } \\
\text { Compliance }\end{array}$ & $\begin{array}{c}\text { Temperature } \\
\left({ }^{\circ} \mathrm{C} .\right)\end{array}$ & $\begin{array}{c}\text { Final } \\
\text { Compliance }\end{array}$ & $\begin{array}{c}\text { Temperature } \\
\left({ }^{\circ} \mathrm{C} .\right)\end{array}$ \\
\hline 4 & 0.083 & 37.0 & 0.054 & 20.0 \\
5 & $0 \cdot 100$ & 35.5 & 0.078 & 23.0 \\
6 & 0.120 & 37.0 & 0.080 & 20.0 \\
\hline
\end{tabular}

Compliance is expressed in litres/cm. $\mathrm{H}_{2} \mathrm{O}$.

1 litre of air plotted against time on bypass. There is a slight decrease in compliance in three sheep, and the other two are virtually unchanged (Table III).

In the fourth group of sheep, in which biventricular bypass and hypothermia were combined, the elasticity curves over the range of cooling and rewarming show a sigmoid contour. During the cooling phase the lungs became less elastic as they did in group 2. Rewarming produced a steady increase in compliance until a point between $24^{\circ}$ and $30^{\circ} \mathrm{C}$. was reached, at which the change reversed and the lungs rapidly decreased in compliance (Fig. 4). The lung compliances at the start of bypass, at their lowest point during cooling, at the change-over point, and at the completion of rewarming are shown in Table IV. The histological features of the lungs following this procedure showed no abnormal changes. A representative sample is shown in Figure 5.

In the fifth group of three sheep the excised lungs showed little change in compliance at $37^{\circ}$ and $15^{\circ} \mathrm{C}$. (Table V).

\section{DISCUSSION}

Much work on lung compliance during cardiopulmonary bypass has been done (Guastavino et

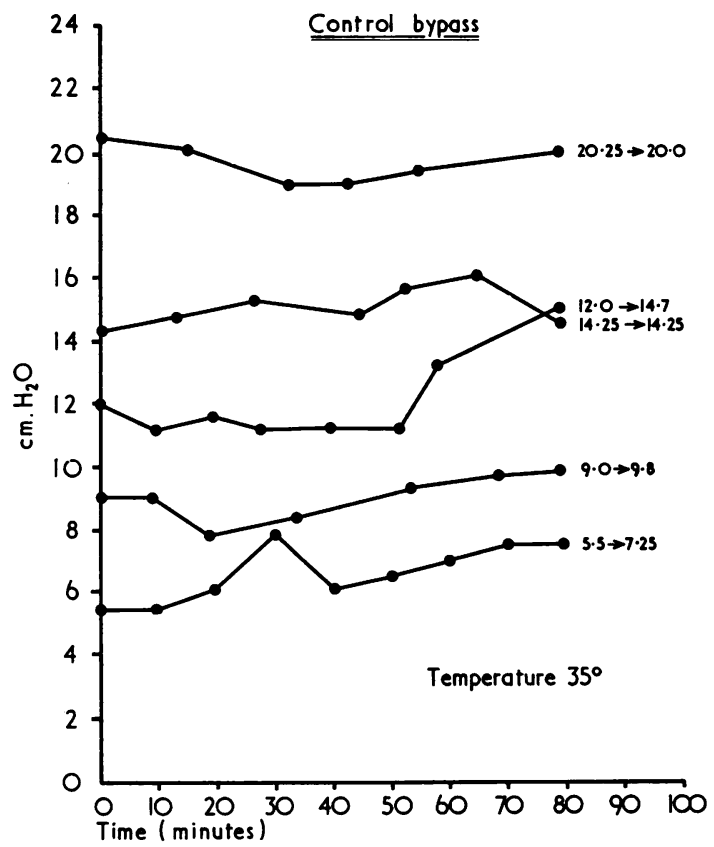

FIG. 3. Pressure-volume relationships of the lungs of five sheep subjected to biventricular bypass at $35^{\circ} \mathrm{C}$. There was little change in the pressures required to inflate the lungs with 1 litre of air.

T A B L E I I I

EFFECT OF BIVENTRICULAR BYPASS WITHOUT TEMPERATURE CHANGE

\begin{tabular}{c|c|c}
\hline Sheep No. & $\begin{array}{c}\text { Initial } \\
\text { Compliance }\end{array}$ & $\begin{array}{c}\text { Final } \\
\text { Compliance }\end{array}$ \\
\hline 7 & 0.049 & $0 \cdot 050$ \\
8 & 0.083 & 0.068 \\
9 & 0.111 & 0.102 \\
10 & 0.182 & $0 \cdot 138$ \\
11 & 0.070 & 0.070 \\
\hline
\end{tabular}

Compliance is expressed in litres/cm. $\mathrm{H}_{2} \mathrm{O}$. 


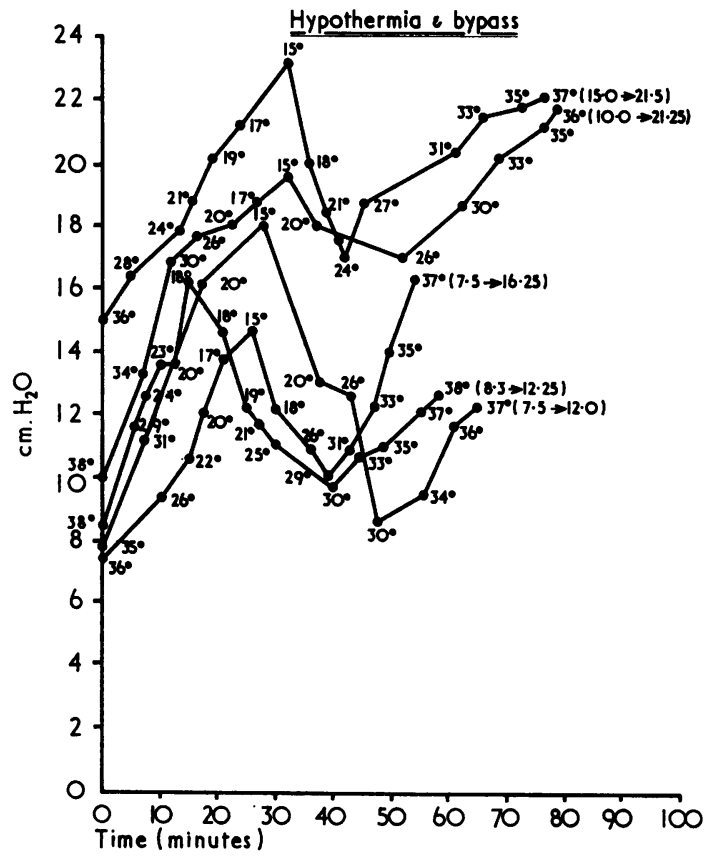

FIG. 4. Pressure-volume relationships of the lungs of five sheep subjected to biventricular bypass, cooled and then rewarmed. The pressures required to inflate the lungs with 1 litre of air increased as the animals were cooled, and decreased as they were rewarmed until a critical temperature was reached when the pressures increased.

T A B L E I V

EFFECT OF COOLING FOLLOWED BY REWARMING USING BIVENTRICULAR BYPASS

\begin{tabular}{|c|c|c|c|c|c|c|c|c|}
\hline $\begin{array}{c}\text { Sheep } \\
\text { No. }\end{array}$ & $\begin{array}{c}\text { Initial } \\
\text { Com- } \\
\text { pliance }\end{array}$ & $\underset{\left({ }^{\circ} \mathrm{C} .\right)}{\text { Temp. }}$ & $\begin{array}{l}\text { Lowest } \\
\text { Point } \\
\text { Com- } \\
\text { pliance }\end{array}$ & $\begin{array}{c}\text { Temp. } \\
\left({ }^{\circ} \mathrm{C} .\right)\end{array}$ & $\begin{array}{l}\text { Change } \\
\text { Point } \\
\text { Com- } \\
\text { pliance }\end{array}$ & $\begin{array}{l}\text { Temp. } \\
\left.\text { ( }{ }^{\circ} \mathrm{C} .\right)\end{array}$ & $\begin{array}{c}\text { Final } \\
\text { Com- } \\
\text { pliance }\end{array}$ & $\begin{array}{l}\text { Temp. } \\
\left({ }^{\circ} \mathrm{C} .\right)\end{array}$ \\
\hline $\begin{array}{l}12 \\
13 \\
14 \\
15 \\
16\end{array}$ & $\begin{array}{l}0.067 \\
0.100 \\
0.120 \\
0.132 \\
0.138\end{array}$ & $\begin{array}{l}36 \cdot 0 \\
38 \cdot 0 \\
38 \cdot 0 \\
35 \cdot 0 \\
36 \cdot 0\end{array}$ & $\begin{array}{l}0.043 \\
0.051 \\
0.062 \\
0.056 \\
0.069\end{array}$ & $\begin{array}{l}15.0 \\
15.0 \\
18.0 \\
15.0 \\
15.0\end{array}$ & $\begin{array}{l}0.061 \\
0.060 \\
0.110 \\
0.125 \\
0.100\end{array}$ & $\begin{array}{l}24 \cdot 0 \\
26 \cdot 0 \\
30 \cdot 0 \\
30 \cdot 0 \\
29 \cdot 0\end{array}$ & $\begin{array}{l}0.046 \\
0.047 \\
0.081 \\
0.083 \\
0.061\end{array}$ & $\begin{array}{l}37 \cdot 0 \\
36 \cdot 0 \\
38 \cdot 0 \\
37 \cdot 0 \\
37 \cdot 0\end{array}$ \\
\hline
\end{tabular}

Compliance is expressed in litres $/ \mathrm{cm} . \mathrm{H}_{2} \mathrm{O}$.

al., 1960 ; Cartwright, Lim, Luft, and Palich, 1962 ; Edmunds and Austen, 1966; Ellison and Ellison, 1966 ; Sullivan et al., 1966 ; Deal, Osborn, Miller, and Gerbode, 1968). Observed changes seem to be related to the state of ventilation during bypass. Edmunds and Austen (1966) found that so long as the lung was ventilated throughout

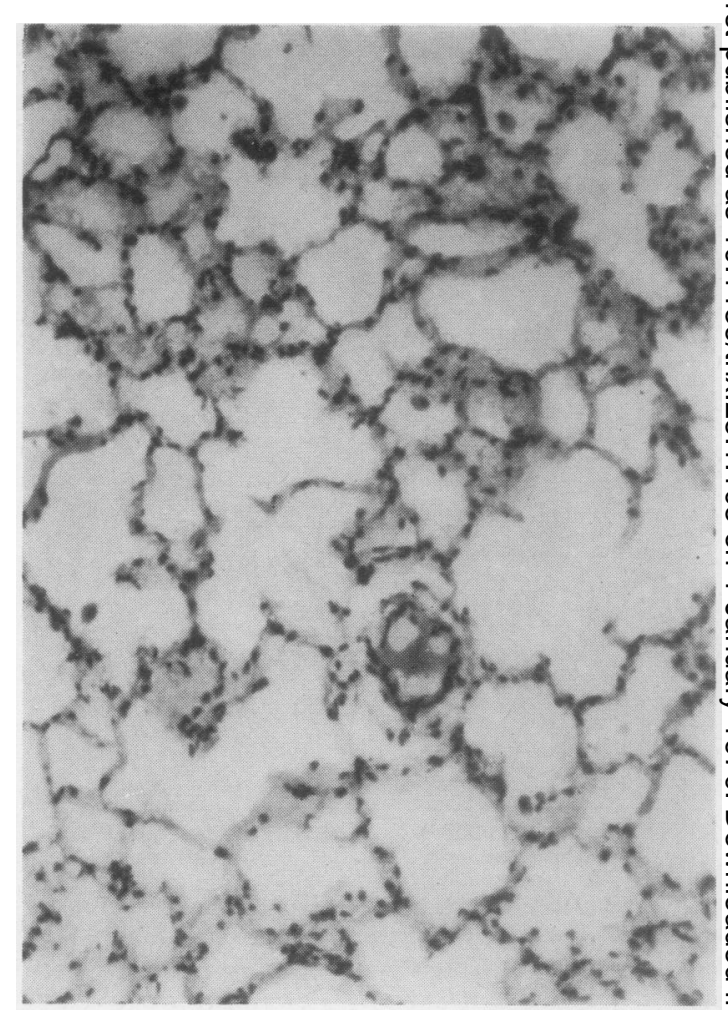

FIG. 5. A photomicrograph of a section of lung from $a^{3}$ sheep subjected to biventricular bypass, hypothermia, and rewarming. No abnormal changes are seen.

T A B L E V

EFFECT OF COOLING EXCISED LUNGS

\begin{tabular}{|c|c|c|c|c|}
\hline $\begin{array}{c}\text { Sheep } \\
\text { No. }\end{array}$ & $\begin{array}{c}\text { Initial } \\
\text { Compliance }\end{array}$ & $\begin{array}{c}\text { Temperature } \\
\left({ }^{\circ} \mathrm{C} .\right)\end{array}$ & $\underset{\text { Compliance }}{\text { Final }}$ & $\begin{array}{c}\text { Temperature } \\
\left({ }^{\circ} \mathrm{C} .\right)\end{array}$ \\
\hline $\begin{array}{l}17 \\
18 \\
19\end{array}$ & $\begin{array}{l}0.094 \\
0.123 \\
0.114\end{array}$ & $\begin{array}{l}37 \cdot 0 \\
37 \cdot 0 \\
37 \cdot 0\end{array}$ & $\begin{array}{l}0.100 \\
0.114 \\
0.128\end{array}$ & $\begin{array}{l}15.0 \\
15.0 \\
15.0\end{array}$ \\
\hline
\end{tabular}

bypass, there was no change in the compliance This agrees with our studies done on respiratory work (Deal, Osborn, Louis, Elliott, and Gerbode, 1967) in relation to cardiopulmonary bypasso Ellison and Ellison (1966), Cartwright et al. (1962)® and Guastavino et al. (1960) have described de-creasing compliance after cardiopulmonary bypass $\rightarrow 0$ The lungs in the patients of Ellison and Ellison and of Cartwright et al. had been statically in $\frac{\rho}{9}$ flated; Guastavino et al. do not mention ventila@ tion details. 
In our control series there was no change in compliance related to anaesthesia for three hours and a slight tendency to decreased compliance with 80 minutes of lung perfusion at $35^{\circ} \mathrm{C}$. In the excised lungs there was no change in compliance due to cooling without perfusion. In the two groups of sheep subjected to hypothermia there was a steady decrease in compliance. The slope plots in Figs 2 and 4 are roughly parallel, from which it seems that the process in both is similar.

In group 4, in which hypothermia and subsequent rewarming was added to the bypass, the lungs became progressively less compliant during cooling. In Fig. 4 it can be seen in the rewarming stages that the lungs became more compliant until the temperature reached $24^{\circ}-30^{\circ} \mathrm{C}$., then the graph assumes a sigmoid shape as the lungs again became less compliant. This drop in compliance persisted for the two hours studied after perfusion.

The decreasing compliance with hypothermia could not be attributed to vascular engorgement (Bondurant, Hickam, and Isley, 1957) as the left atrium was continuously drained and decompressed, and the pulmonary artery pressure did not rise above $16 \mathrm{~mm}$. $\mathrm{Hg}$. The decrease in compliance with cooling and the initial increase in compliance with rewarming seem to be part of a similar process. The subsequent cause of decreasing compliances with further rewarming is more difficult to understand and the events are suggestive of lung damage. Lung perfusion and anaesthesia causing pulmonary oedema, either overt or interstitial, appear to be ruled out by the lack of changes in the control series. Further, histological examination of these lungs showed nothing to suggest such an aetiology. We have shown that hypothermia down to profound levels produces a persistent decrease in compliance in sheep. The lack of other factors makes it seem possible that the observed changes are due to surfactant alterations or loss, similar to those changes described by Clements (1962) and Waldhausen, Giammona, Kilman, and Daly (1965).

The persistent and severe nature of the compliance changes noted by us following profound hypothermia with perfusion in sheep causes us to suggest that our findings be considered before this technique is undertaken either as a direct medical procedure or in the preservation of lung tissue for transplantation in man.

\section{REFERENCES}

Allen, J. M., Estes, J. T., and Mansberger, A. R. (1960). The use of hypothermia in septic shock. Amer. Surgn, 26, 11.

Bendixen, H. H., Egbert, L. D., Hedley-Whyte, J., Laver, M. B., and Pontoppidan, H. (1965). Respiratory Care, p. 50. C. V. Mosby, St. Louis.

Bigelow, W. G., Callaghan, J. C., and Hopps, J. A. (1950). General hypothermia for experimental intracardiac surgery. Ann. Surg., hypother 531 .
132,

Bondurant, S., Hickam, J. B., and Isley, J. K. (1957). Pulmonary and circulatory effects of acute pulmonary vascular engorgement in normal subjects. J. clin. Invest., 36, 59.

Cartwright, R. S., Lim, T. P. K., Luft, U. C., and Palich, W. E. (1962). Pathophysiological changes in the lungs during extracorporeal circulation. Circulat. Res., 10, 131.

Clements, J. A. (1962). Surface phenomena in relation to pulmonary function. Physiologist, 5, 11.

Deal, C. W., Osborn, J. J., Louis, E., Elliott, S., and Gerbode, F. (1967). Respiratory work in relation to cardiopulmonary bypass. Thorax, 22, 139.

- Ellis, E., and Gerbode, F. (1968). Chest wall compliance. Ann. Surg., 167, 73.

Miller, G. E., and Gerbode, F. (1968). Pulmonary compliance in congenital heart disease and its relation to cardiopulmonary bypass. J. thorac. cardiovasc. Surg., 55, 320.

Dean, R. B., and Visscher, M. B. (1941). The kinetics of lung ventilation. Amer. J. Physiol., 134, 450.

Drew, C. E., Keen, G., and Benazon, B. D. (1959). Profound hypothermia. Lancet, I, 745 .

Edmunds, L. H. , and Austen, W. G. (1966). Effect of cardiopulmonary bypass on pulmonary volume-pressure relationships and vascular resistance. J. appl. Physiol., 21, 209.

Ellison, L. T., and Ellison, R. G. (1966). Pulmonary compliance following open-heart surgery and its relationship to ventilation and gas exchange. Circulation, 34, Suppl. III, p. 95.

Gowen, G. F., and Lindenmuth, W. W. (1961). General hypothermia for managing gastrointestinal hemorrhage. J. Amer. med. Ass., $175,29$.

Guastavino, G. N., Wikinski, J. A., Andres, R. H., Donadei, C. A., and Quinterno, J. E. (1960). Modification of lung compliance during perfusion with pump-oxygenator (experimental). Dis. Chest, 38, 170.

Harley, H. R. S. (1964). The use of hypothermia and dehydration in the treatment of severe cerebral hypoxia. Brit. J. Anaesth., 36, 581 .

Judd, B. C., and King, B. D. (1967). Human lung compliances during prolonged positive pressure ventilation. Anesthesiology, 28, 257.

Lorhan, P. H., and Brookler, H. A. (1961). Carbon monoxide poisoning: management with hypothermia. Anesth. Analg. Curr. Res., 40, 502.

Mead, J., and Collier, C. (1959). Relation of volume history of lungs to respiratory mechanics in anesthetized dogs. J. appl. Physiol., 14,669 .

Michenfelder, J. D., Terry, H. R., Daw, E. F., MacCarty, C. S., and Uihlein, A. (1963). Profound hypothermia in neurosurgery: Open-chest versus closed-chest techniques. Anesthesiology, 24, 177.

Sullivan, S. F., Patterson, R. W., Malm, J. R., Bowman, F. O., and Papper, E. M. (1966). Effect of heart-lung bypass on the mechanics of breathing in man. J. thorac. cardiovasc. Surg., 51, 205.

Waldhausen, J., Giammona, S. T., Kilman, J. W., and Daly, W. J. (1965). Effect of transplantation of canine lung on pulmonary compliance and surfactant. J. Amer. med. Ass., 191, 1002. 